\title{
PENGARUH DIGITAL MARKETINGTERHADAP ORGANIZATIONAL PERFORMANCE DENGANINTELLECTUAL CAPITAL DAN PERCEIVED QUALITYSEBAGAI VARIABEL INTERVENING PADA INDUSTRI HOTEL BINTANG TIGA DI JAWA TIMUR
}

\author{
Willy Andrian Prabowo \\ Pengamat Industri Perhotelan di Surabaya \\ E-mail: willyap@gmail.com
}

\begin{abstract}
Abstrak: Pengaruh Pemasaran Digital terhadap organizational performance dengan intellectual capital dan perceived quality sebagai variabel intervening dalam Industri Tiga Bintang Perhotelan di Jawa Timur. Pertumbuhan pariwisata di Indonesia semakin pesat. Keinginan orang untuk berlibur berkembang selama bertahun-tahun. Hal ini membuat persaingan yang ketat dalam Industri Perhotelan di Jawa Timur. Penelitian ini bertujuan untuk menganalisis pengaruh Pemasaran Digital (Interaktif, Program Insentif, desain Situs, Biaya), terhadap organizational performance di Industri Hotel di Jawa Timur dengan intellectual capital (Sumber Daya Manusia, Modal Pelanggan, Modal Struktural) dan perceived quality (Tangibles, Reliability, Responsiveness, Assurance, Empathy), sebagai variabel intervening. Penelitian ini dilakukan dengan menyebarkan kuesioner kepada 120 responden karyawan internal Three Star Hotel di Jawa Timur. Teknik analisis yang digunakan dalam analisis kuantitatif teknis dengan metode analisis jalur
\end{abstract}

Kata kunci: Pemasaran Digital, Organizational performance, Intellectual Capital, Perceived Quality.

\begin{abstract}
The influence of Digital Marketing on Organizational Performance with Intellectual Capital and Perceived Quality as an intervening variables in Three Star Hospitality Industry in East Java.The growth of tourism in Indonesia is growing abundantly. People's desire for vacation is developing through the years. This enables intense competiton in the Hospitality Industry in East Java.This research aims to analyze the influece of Digital Marketing (Interactive, Incentive Programs, Site design, Cost), to Organizational Performance in Hotel Industry in East Java with Intellectual Capital (Human Capital, Customer Capital, Structural Capital) and Perceived Quality (Tangibles, Reliability, Responsiveness, Assurance, Empathy), as an intervening variables.This research was conducted by distributing questionnaires to 120 respondents internal employees of Three Star Hotel in East Java. Analytical technique used in technical quantitative analysis with path analysis method.
\end{abstract}

Keywords: Digital marketing, Organizational performance, Intellectual Capital, Perceived Quality.

\section{PENDAHULUAN}

Pariwisata merupakan salah satu sumber devisa negara selain dari sektor migas yang sangat potensial dan mempunyai andil besar dalam membangun perekonomian Negara walaupun saat ini partumbuhannya masih sangat lambat. Telah kita ketahui bersama bahwa di Negara kita Indonesia memiliki beraneka ragam objek wisata dan budaya yang terbentang dari Sabang sampai Marauke, mulai dari objek wisata yang kaya akan keindahan alam, taman wisata, taman budaya,dan wisata kulinernya banyak orang menyebutkan indonesia adalah surga dunia yang memiliki banyak keanekaragaman wisata yang begitu indah dan memiliki khas di mana tiap daerahnya memiliki kebudayaan yang berbeda beda yang melambangkan cirikhas dari daerah tersebut dan banyak turis baik turis domestic maupun macanegara yang mengagumi keanekaragaman budaya dan wisata di Negara Indonesia.

Kondisi ini kemudian membuat persaingan hotel di beberapa area cenderung sangat kompetitif. Para pengelola hotel bahkan berlomba-lomba memasang tarif semurah mungkin terhadap unit-unit kamarnya, jika tidak mereka tidak akan mendapatkan pengunjung. Persaingan pun tak hanya terjadi pada hotel dengan kelas yang sama, melainkan juga pada kelas yang lebih tinggi atau lebih rendah. Hal ini kemudian semakin menjadi dengan kondisi pasar yang semakin ketat.

Internet sangat bermanfaat mengenalkan potensi wisata daerah kepada semua orang baik dalam skala nasional maupun internasional. Pihak-pihak yang berkepentingan seperti pemerintah daerah, perusahaan travel, pengusaha hotel, pengusaha restoran, dsb dapat menyediakan sebuah website yang bisa diakses oleh semua orang mengenai potensi wisata yang ada di daerah tersebut. Pengaruh Digital Marketing itu sangat besar.

Hal ini tak lepas dari peran sales \& marketing department yang dituntut secara profesional dalam melakukan strategi pemasaran untuk mengenalkan dan mempromosikan hotel dan produknya karena dengan menggunakan media promosi secara online, 
segmen pasar yang dituju menjadi lebih luas karena dapat di akses oleh masyarakat secara global.

Digital Marketing juga berhubungan dengan Organizational Performance, Organizational Performance adalah kemampuan melaksanakan tugas-tugas yang dibebankan kepada organisasi dengan sebaikbaiknya guna mencapai sasaran yang telah disepakati. Dalam hal ini Digital Marketing sangat membantu pencapaian-pencapaian yang berhasil diraih organisasi, salah satunya adalah peningkatan penjualan yang didapat dengan bantuan Digital Marketing.

\section{Digital Marketing}

Digital Marketing membantu sebuah perusahaan dalam mepromosikan dan memasarkan produk maupun jasa yang mereka punya. Digital Marketing juga dapat membuat atau membuka pasar-pasar baru yang sebelunya tertutup karena adanya keterbatasan waktu, cara komunikasi, maupun jarak.

Eun Young Kim (2002) menetapkan empat dimensi Digital Marketing. Empat dimensi Digital Marketing adalah variabel independen yang membantu keberhasilan usaha sebagai variabel dependen. Empat dimensi tersebut yang dikenal sebagai berikut:

a) Interactive

b) Incentive Programs

c) Site design

d) Cost

\section{Intellectual Capital}

Stewart (1997) mengatakan bahwa Intellectual Capital adalah aset perusahaan yang telah diformalisasi, dilatih, dan dikembangkan untuk menciptakan nilai aset yang melebihi ekspektasi. Intellectual Capital sangat penting untuk dimiliki sebuah perusahaan, dengan Intellectual Capital yang memadai, kinerja perusahaan tentunya akan meningkat dan memiliki hasil positif.

Fragouli Evaggelia (2008) menetapkan tiga dimensi Digital Marketing. Tiga dimensi Intellectual Capitaladalah variabel independen yang membantu keberhasilan usaha sebagai variabel dependen. Tiga dimensi tersebut yang dikenal sebagai berikut:
a) Human Capital
b) Customer Capital
c) Structural Capital

\section{Perceived Quality}

Aaker (1991) menyatakan bahwa Perceived Quality memberikan nilai lebih terhadap sebuah brand, kualitas terbaik memberikan alasan yang baik dari para konsumenuntuk membeli brand tersebut dan membuat brand tersebut menjadi berbeda dengan brand lainya, agar dapat bisa memberikan harga yang tinggi, dan memiliki kekuatan dan dasar yang kokoh untuk brand extension.Sebuah produk dinyatakan berkualitas jika dapat memenuhi harapan pelanggan sesuai dengan dimensi-dimensi yang ada. Menurut pendapat Garvin (1984) ada 8 dimensi dalam menentukan kualitas sebuah perusahaan:

1. Performance (unjuk kerja): menyangkut karakteristik operasi dasar.

2. Durability (ketahanan): jangka waktu hidup sebelum tiba saatnya diganti.

3. Serviceability (kemampulayanan): kemudahan servis atau perbaikan ketika dibutuhkan

4. Aesthethics (keindahan): menyangkut tempilan, rasa, bunyi, bau, atau rasa.

5. Perceived Quality (kualitas yang dirasakan): mutu/kualitas yang diterima dan dirasa customer.

6. Conformance (kehandalan): kemungkinan produk untuk tidak berfungsi pada periode waktu tertentu.

7. Reliability (kehandalan): kemungkinan produk untuk tidak berfungsi pada periode waktu tertentu

8. Features (fitur): item-item ekstra yang ditambahkan pada fitur dasar.

\section{Organizational Performance}

Kinerja Organisasi merupakan faktor dan variable penting dalam meningkatkan performa organisasi, konsep ini sering kita temukan dalam proses pengembangan organisasi.

Adapun Anne J Broderick (1998) menetapkan tiga dimensi Organizational Performance. Tiga dimensi Organizational Performance adalah variabel independen yang membantu keberhasilan usaha sebagai variabel dependen. Dimensi tersebut yang dikenal sebagai berikut:
a) Role Set
b) Role Script
c) Role Congruence
d) Role Performance
e) Role Expansion
f) Role Discrepancy
g) Role Conflict

\section{Kerangka Berpikir}

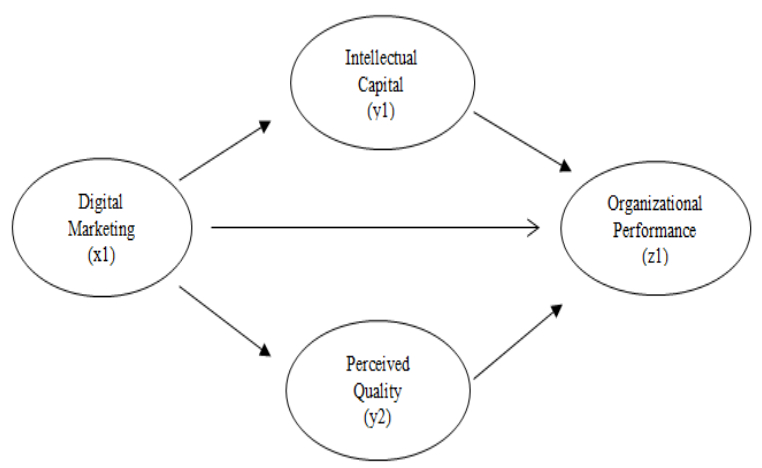

Gambar 1. Model Penelitian 
H1: Digital Marketing berpengaruh positif terhadap Intellectual Capital

H2: Digital Marketing berpengaruh positif terhadap Perceived Quality

H3: Intellectual Capital berpengaruh positif terhadap Organizational Performance

H4: Perceived Quality berpengaruh positif terhadap Organizational Performance

H5: Digital Marketing berpengaruh positif terhadap Organizational Performance

\section{METODOLOGI PENELITIAN}

\section{Populasi}

Populasi adalah gabungan seluruh elemen yang memiliki serangkaian karakteristik serupa, yang mencakup semesta untuk kepentingan masalah riset pemasaran (Malhotra, 2004). Pendapat lainnya mengatakan bahwa populasi adalah wilayah generalisasi yang terdiri dari obyek atau subyek yang mempunyai kualitas dan karakteristik tertentu yang diterapkan oleh peneliti untuk dipelajari dan kemudian ditarik kesimpulannya (Sugiyono, 2009). Populasi dalam penelitian ini adalah internal dari industri hotel bintang empat di Jawa Timur.

\section{Sampel}

Sampel adalah sebagian dari populasi yang ditetapkan oleh peneliti (Sugiyono, 2009). Dalam melakukan survei tidak perlu untuk meneliti semua individu dalam populasi karena akan banyak biaya dan waktu. Namun, syarat utama sampel yang baik yaitu apabila sampel yang diambil mewakili ciri dan karakteristik populasi (representatif) dengan bias yang kecil (Sugiyono, 2009)

\section{Definisi Operasional Variable}

\section{Digital Marketing (X1)}

a. Transaction / Cost

Merupakan salah satu teknik promosi yang memliki tingkat efisiensi yang tinggi sehingga dapat menekan biaya dan waktu transaksi.

b. Incentive Program

Program-program yang menarik tentu menjadi keunggulan dalam setiap promosi yang dilakukan. Program-program ini juga diharapkan agar dapat memberikan nilai yang lebih kepada perusahaan.

c. Site Design

Merupakan tampilan menarik dalam media Digital Marketingyang dapat memberikan nilai positif bagi perusahaan.

d. Interactive

Merupakan hubungan dua arah antara pihak perusahaan dengan konsumen yang dapat memberikan info dan dapat diterima dengan baik dan jelas.

\section{Intellectual Capital (Y1)}

a. Human Capital

Merupakan sekumpulan aset tidak berwujud yang mencerminkan kemampuan dalam perusahaan berupa pengetahuan yang dimiliki dalam bentuk pekerja profesional mereka

b. Structural Capital

Merupakan struktur perusahaan yang mendukung usaha dari pekerja pada perusahaan tersebut untuk dapat menghasilkan kinerja intelektual yang optimal.

c. Customer Capital

Adalah hubungan antara perusahaan dengan mitra kerja dan pihak eksternal perusahaan baik itu berasal dari pelanggan, pemasok, maupun hubungan antara perusahaan dengan pemerintah atau masyarakat sekitar.

Perceived Quality (Y2)

a. Features yaitu nilai tambah atau inovasi baru yang ditambahkan pada fitur dasar. Sehingga dapat sesuai dengan kebutuhan pelanggan.

b. Reliability yaitu kemungkinan produk atau jasa mampu memenuhi kebutuhan atau keinginan pelanggan sehingga mampu memenuhi cita-cita pelanggan.

c. Conformance yaitu kesesuaian kinerja dan mutu produk dengan janji yang diberikan oleh perusahaan kepada konsumen.

d. Durability yaitu berhubungan dengan jangka waktu atau masa guna barang atau jasa yang digunakan dalam satu periode tertentu.

e. Serviceability yaitu kemudahan mendapatkan pelayanan dan informasi yang dibutuhkan oleh pelanggan.

f. Aesthetics yakni menyangkut dengan keindahan atau penampilan dan penyajian pelayanan atau jasa.

Organizational Performance (Z1)

a. Role Set yaitu peran set internal yang dibentuk melalui hubungan dan pemahaman tentang komitmen peran kerja dengan penyedia layanan.

b. Role Script yaitu perilaku peran yang diharapkan, berlaku atau dikembangkan dalam pelayanan antarmuka dengan klien.

c. Role Congruence terjadi ketika pemahaman yang jelas tentang harapan peran ada dan terpenuhi.

d. Role Expansion, yaituperubahan peran dialami melalui tanggung jawab meningkat.

e. Role Discrepancy, yaitu kesenjangan yang terjadi di bawah pemenuhan antara aktual dan aspek direncanakan.

\section{ALAT ANALISA}

\section{Path Analysis}

Metode pengujian statistik yang akan digunakan pada model path analysis di penelitian ini adalah Partial Least Square. Partial Least Square (PLS) adalah bagian dari Structural Equation Modelling (SEM). Metode PLS ini merupakan metode baru yang sudah banyak dipakai dalam penenlitian karena dapat menggunakan jumlah sampel yang sedikit. Kelebihan dari PLS-SEM adalah metode ini mampu menyelesaikan berbagai model yang rumit/kompleks 
dengan berbagai variabel endogen dan variabel eksogen dengan banyaknya indikator yang ada, dapat dipakai pada sampel dengan jumlah kecil, dan dengan data distribusi yang ada (Abdillah \& Hartono, 2015).

\section{T-test}

Di dalam penelitian ini terdapat variabel intervening yaitu penghubung antara variabel dependen dan variabel independen. Pengujian hipotesis mediasi (variabel intervening) dapat dilakukan dengan prosedur $t$-test. Pengujian $t$-test digunakan untuk mendapatkan nilai $\mathrm{t}$-statistik yang diperlukan apabila peneliti ingin melakukan uji hipotesis, sehingga peneliti dapat mengatakan pengaruh sebuah variabel dapat dikatakan memiliki pengaruh yang signifikan atau tidak. $T$-test dilakukan dengan menggunakan metode bootstrapping.

Metode bootstrapping adalah suatu proses pengujian re-sampling yang dilakukan oleh sistem komputer untuk mengukur akurasi pada sample estimate. Bootstraping digunakan untuk mengukur akurasi pada sample. Apabila nilai bootstrap lebih dari (>) 1.96 maka dinyatakan bahwa variabel tersebut memiliki pengaruh yang signifikan sedangkan apabila nilai bootstrap lebih rendah $(<)$ dari 1.96, maka dinyatakan pengaruh variabel tersebut lemah (Abdillah \& Hartono, 2015).

\section{Statistik deskriptif}

Statistik deskriptif digunakan untuk menyajikan data secara deskriptif yang menggambarkan karakteristik responden serta jawaban-jawaban responden sehingga mampu digunakan sebagai kesimpulan dari hasil kuisioner yang sudah disebarkan selama penelitian ini.

\section{ANALISA DAN PEMBAHASAN}

\section{Analisa Deskriptif}

Tabel 1. Analisa Deksriptif Dimensi Transaction/Cost

\begin{tabular}{|l|c|c|c|c|c|c|c|}
\hline \multirow{2}{*}{\multicolumn{1}{|c|}{ Indikator }} & \multicolumn{5}{c|}{ Jawaban } & \multirow{2}{*}{ Mean } & $\begin{array}{c}\text { Std. } \\
\text { Dev. }\end{array}$ \\
\cline { 2 - 7 } & STS & TS & N & S & SS & & \\
\hline $\begin{array}{l}\text { Digital Marketing } \\
\text { mengurangi biaya promosi } \\
\text { konvensional (X1.1) }\end{array}$ & 0 & 7 & 31 & 67 & 15 & 3,75 & 0,744 \\
\hline $\begin{array}{l}\text { Digital Marketing } \\
\text { mempersingkat waktu } \\
\text { transaksi (X1.2) }\end{array}$ & 0 & 5 & 32 & 67 & 16 & 3,78 & 0,721 \\
\hline
\end{tabular}

Indikator X1.1 memiliki nilai rata-rata sebesar 3,75 yang menunjukan bahwa secara umum karyawan sudah merasa bahwa Digital Marketing yang ada dapat membantu perusahaan dalam mengurangi biaya promosi yang seharusnya dilakukan secara konven- sional seperti brosur, baliho, spanduk, dll. Hal ini dikarenakan biaya besar yang seharusnya dihabiskan untuk promosi konvensional dapat dialokasikan ke pembuatan web dan promosi digital yang jauh lebih efisien secara biaya. Seperti contohnya adalah Fave Hotel dan Yellow Hotel yang telah menggunakan Facebook maupun Instagram.

Transaction/Cost mencerminkan kemampuan Industri Hotel Bintang Tiga untuk dalam menggunakan teknologi informasi sehingga dapat mengurangi biaya maupun kinerja dalam transaksi yang terjadi. Pada Tabel 1 menjelaskan bahwa nilai mean terbesar dapat ditemui pada indikator X1.2 sebesar 3,78. Nilai ini menjelaskan bahwa mayoritas karyawan setuju terhadap pertanyaan mengenai adanya perkembangan tenologi informasi dapat meningkatkan dan mempersingkat waktu transksi yang terjadi. Digital Marketing yang memiliki dimensi transaction/cost ini juga berpengaruh besar terhadap penyampaian informasi dari pihak employee, para karyawan tidak perlu menyampaikan infomasi yang sudah umum karena para pelanggan juga dapat melihat informasi tersebut secara virtual.

Tabel 2. Analisa Deksriptif Dimensi Incentive Program

\begin{tabular}{|l|c|c|c|c|c|c|c|}
\hline \multirow{2}{*}{ Indikator } & \multicolumn{5}{|c|}{ Jawaban } & \multirow{2}{*}{ Mean } & $\begin{array}{c}\text { Std. } \\
\text { Dev. }\end{array}$ \\
\cline { 2 - 7 } & STS & TS & N & S & SS & & \\
\hline $\begin{array}{l}\text { Digital Marketing } \\
\text { memberikan informasi } \\
\text { yang jelas (X1.3) }\end{array}$ & 0 & 6 & 29 & $6 / 5$ & 19 & 3,82 & 0,744 \\
\hline $\begin{array}{l}\text { Digital Marketing } \\
\text { membantu karyawan } \\
\text { menjelaskan produk dan } \\
\text { layanan (X1.4) }\end{array}$ & 0 & 2 & 24 & 75 & 19 & 3,93 & 0,721 \\
\hline
\end{tabular}

Indikator X1.3 memiliki nilai Mean yang cukup tnggi, yaitu 3,82, situs maupun jejaring sosial yang dimiliki perusahaan, hal ini dapat dibuktikan dari website yang dimiliki oleh perusahaan, karyawan setuju dengan pernyataan bahwa website yang perusahaan mereka miliki dapat memberikan informasi dengan jelas.

Digital Marketing membantu karyawan menjelaskan produk dan layanan, hal ini menandakan bahwa para karyawan setuju bahwa Digital Marketing membantu dalam memberikan informasi yang jelas, dalam artian, situs maupun akun jejaring sosial yang perusahaan gunakan membantu karyawan dalam menjelaskan informasi tentang produk-produk yang dimiliki oleh perusahaan, dengan begitu, kinerja karyawan bisa dialokasikan ke hal-hal lain yang lebih penting. Dengan didukung nilai Mean 3.93, dapat disimpulkan bahwa Digital arketing telah membantu karyawan menjelaskan produk dan layanan yang perusahaan miliki. 
Tabel 3. Analisa Deksriptif Dimensi Site Design

\begin{tabular}{|c|c|c|c|c|c|c|c|}
\hline \multirow{2}{*}{ Indikator } & \multicolumn{5}{|c|}{ Jawaban } & \multirow{2}{*}{ Mean } & $\begin{array}{c}\text { Std. } \\
\text { Dev. }\end{array}$ \\
\cline { 2 - 8 } & STS & TS & N & S & SS & & \\
\hline $\begin{array}{l}\text { Desain Digital Marketing } \\
\text { menarik (X1.5) }\end{array}$ & 0 & 7 & 29 & 57 & 27 & 3,87 & 0,753 \\
\hline $\begin{array}{l}\text { Desain Digital Marketing } \\
\text { tersusun dengan rapi (X1.6) }\end{array}$ & 0 & 7 & 27 & 61 & 25 & 3,87 & 0,648 \\
\hline
\end{tabular}

Site Design yang menarik merupakan salah satu faktor penting dalam menyusun Digital Marketing. Hal ini terbukti dengan nilai Mean yaitu 3,87. Indikator ini menunjukan bahwa Industri Hotel Bintang Tiga membutuhkan desain yang menarik. Desain situs yang menarik dapat membantu para karyawan dalam memberikan informasi kepada para pelanggan. Mean X1.5 dan X1.6 menunjukan bahwa kedua indikator merupakan faktor yang penting dalam dimensi Site Design.

Sedangkan Indikator X1.6 memiliki nilai Mean yaitu 3.87, nilai ini merupakan angka yang cukup tinggi, hal ini dapat diartikan bahwa site design yang rapi dapat membantu karyawan dalam melakukan pekerjaannya. Hal ini dikarenakan Site Design yang menarik dan Rapi membuat para pelanggan dapat membaca informasi secara jelas dan cepat sehingga akan berdampak pada kecepatan karyawan dalam menyampaikan informasi inti.

Tabel 4. Analisa Deksriptif Dimensi Interactive

\begin{tabular}{|c|c|c|c|c|c|c|c|}
\hline \multirow{2}{*}{ Indikator } & \multicolumn{5}{|c|}{ Jawaban } & \multirow{2}{*}{ Mean } & $\begin{array}{c}\text { Std. } \\
\text { Dev. }\end{array}$ \\
\cline { 2 - 8 } & STS & TS & N & S & SS & & \\
\hline $\begin{array}{l}\text { Digital Marketing memudahkan } \\
\text { karyawan berkomunikasi } \\
\text { dengan konsumen (X1.7) }\end{array}$ & 0 & 10 & 30 & 58 & 22 & 3,77 & 0,826 \\
\hline $\begin{array}{l}\text { Digital Marketing membantu } \\
\text { karyawan dalam menanggapi } \\
\text { komplain (X1.8) }\end{array}$ & 0 & 10 & 25 & 65 & 20 & 3,79 & 0,806 \\
\hline
\end{tabular}

Digital Marketing dengan dimensi interactive terbukti mempermudah karyawan dalam menjalankan proses komunikasi dengan konsumen, hal ini dapat dibuktikan dengan situs hotel yang dapat menampung komentar serta kritik dan saran yang diberikan oleh para pelanggan. Dalam Situs tersebut dapat diberikan nomor telpon bagi yang kurang berkenan dan ingin menyampaikan opininya secara langsung. Dengan nilai mean X1.7 3,77, menunjukan bahwa karyawan setuju dengan pernyataan bahwa Digital Marketing memudahkan karyawan dalam berkomunikasi dengan konsumen. Hal ini harus diperhatikan oleh perusahaan karena dengan berjalannya komunikasi yang baik maka akan terbentuk relasi yang berbanding lurus.

Komplain yang disampaikan oleh pelanggan juga dapat ditanggapi oleh pihak karyawan dengan cepat, karena komplain yang masuk merupakan komplain real-time atau komplain secara langsung yang dapat dibaca. Situs yang digunakan juga bermanfaat untuk memberikan informasi perusahaan yang dapat bermanfaat bagi para pelanggan. 3,79 merupakan nilai Mean dari indikator X1.8 dapat diartikan bahwa karyawan merasa Digital Marketing membantu karyawan dalam menanggapi komplain, hal ini dikarenakan pilihan komentar dan kritik saran yang dapat ditanggapi langsung oleh perusahaan.

Tabel 5. Analisa Deksriptif Dimensi Human Capital

\begin{tabular}{|l|c|c|c|c|c|c|c|}
\hline \multirow{2}{*}{ Indikator } & \multicolumn{5}{|c|}{ Jawaban } & \multirow{2}{*}{ Mean } & $\begin{array}{c}\text { Std. } \\
\text { Dev. }\end{array}$ \\
\cline { 2 - 6 } & STS & TS & N & S & SS & & \\
\hline $\begin{array}{l}\text { Digital Marketing memudahkan } \\
\text { karyawan dalam belajar produk } \\
\text { (Y1.1) }\end{array}$ & 0 & 6 & 25 & 68 & 21 & 3,87 & 0,844 \\
\hline $\begin{array}{l}\text { Digital Marketing memudahkan } \\
\text { karyawan dalam memberikan } \\
\text { layanan (Y1.2) }\end{array}$ & 0 & 5 & 29 & 59 & 27 & 3,90 & 0,815 \\
\hline
\end{tabular}

Human Capital merupakan dimensi yang berhubungan langsung dengan Digital Marketing, dalam hal ini Human Capital terbantu dengan adanya Digital Marketing dalam hal memudahkan karyawan mempelajari produk-produk perusahaan yang ada. Dengan adanya teknologi informasi digital, karyawan dapat mempelajari produk dengan cepat, bantuan teknologi informasi seperti powerpoint, bacaan dan internet dapat mempercepat proses pembelajaran para karyawan. Media sosial dan aplikasi obrolan online membantu para karyawan dalam pertukaran informasi sehingga lebih cepat dalam mempelajari produkproduk yang ada. Indikator X2.1 dengan nilai Mean 3,87 juga menjadi pembukti bahwa Digital Marketing yang digunakan dalam memudahkan karyawan dalam pembelajaran produk.

Digital Marketing juga mempermudah pekerjaan karyawan dalam memberikan layanan, dengan nilai mean X2.2 3,9 membuktikan bahwa karyawan setuju dengan pernyataan tersebut, hal ini dapat terjadi karena adanya pertukaran informasi yang cepat antar karyawan, sehingga informasi tersebut akan tersampaikan dengan baik ke pelanggan.

Tabel 6. Analisa Deksriptif Dimensi Structural Capital

\begin{tabular}{|l|c|c|c|c|c|c|c|}
\hline \multirow{2}{*}{ Indikator } & \multicolumn{5}{|c|}{ Jawaban } & \multirow{2}{*}{ Mean } & $\begin{array}{l}\text { Std. } \\
\text { Dev. }\end{array}$ \\
\cline { 2 - 6 } & STS & TS & N & S & SS & & \\
\hline $\begin{array}{l}\text { Digital Marketing } \\
\text { memudahkan } \\
\text { dalam mencari informasi } \\
\text { (Y1.3) }\end{array}$ & 0 & 6 & 21 & 70 & 23 & 3.92 & 0,752 \\
\hline $\begin{array}{l}\text { Digital Marketing } \\
\text { memudahkan karyawan } \\
\text { mempelajari SOP (Y1.4) }\end{array}$ & 0 & 6 & 37 & 48 & 29 & 3,83 & 0,790 \\
\hline
\end{tabular}

Intellectual Capital merupakan sumber daya berkualitas yang menjadi aset perusahaan. Indikator 
Y1.3 memiliki nilai setuju yang cukup besar. Hal ini menyatakan bahwa Digital Marketing memudahkan dan membantu karyawan dalam pencarian informasi yang ada, ini disebabkan karena karyawan dapat mencari informasi tersebut melalui internet, jejaring sosial, maupun situs-situs yang terpercaya. Hal ini memungkinkan karyawan untuk mencari data sekunder secara cepat,aman dan terpercaya, dengan nilai Mean 3,92, dapat kita simpulkan bahwa sebagian besar karyawan memang terbantu dengan adanya Digital Marketing.

Indikator Y1.4 memiliki nilai mean tidak jauh dari indikator diatas dalam dimensi ini yaitu sebesar 3,83dapat dilihat bahwa karyawan dapat mempelajari SOP dengan bantuan Digital Marketing. Hal ini menjelaskan bahwa mayoritas karyawan industri hotel bintang tiga setuju bahwa Digital Marketing yang diterapkan oleh hotel terbukti mempermudah karyawan mempelajari SOP. Proses implementasi yang dibutuhkan untuk memperkanelkan SOP kepada setiap orang yang terlibat dan menjadikan hal tersebut sebagai bagian penting dalam setiap operasi rutin. Digital Marketing sangat berperan di sini karena rekapan dokumen yang didistribusikan sesuai dengan kebutuhan dapat diakses dengan mudah oleh seluruh anggota perusahaan, terutama yang terlibat langsung dalam SOP tersebut.

Tabel 7. Analisa Deksriptif Dimensi Customer Capital

\begin{tabular}{|l|c|c|c|c|c|c|c|}
\hline \multirow{2}{*}{ Indikator } & \multicolumn{5}{|c|}{ Jawaban } & \multirow{2}{*}{ Mean } & $\begin{array}{c}\text { Std. } \\
\text { Dev. }\end{array}$ \\
\cline { 2 - 7 } & STS & TS & N & S & SS & & \\
\hline $\begin{array}{l}\text { Digital Marketing } \\
\text { memampukan karyawan } \\
\text { dekat dengan pelanggan } \\
\text { (Y1.5) }\end{array}$ & 0 & 8 & 26 & 55 & 31 & 3,91 & 0,748 \\
\hline $\begin{array}{l}\text { Digital Marketing } \\
\text { memudahkan karyawan } \\
\text { berkomunikasi dengan } \\
\text { stakeholder (Y1.6) }\end{array}$ & 0 & 5 & 35 & 48 & 32 & 3,89 & 0,850 \\
\hline
\end{tabular}

Customer Capital adalah aset perusahaan yang berupa relasi-relasi yang terjalin dengan para pelanggan. Dengan nilai Mean 3,91, indikator Y1.5 menunjukan bahwa karyawan setuju dengan adanya Digital Marketing yangdapat mendekatkan karyawan dengan pelanggan, yaitu dengan menggunakan jejaring sosial dan Akun untuk berkomunikasi personal, dari sini karyawan dapat mendekati pelanggan secara personal dan hal ini dapat meningkatkan kepercayaan pelanggan terhadap perusahaan itu sendiri.

Pada Indikator Y1.6 ini, nilai Mean yang terdata adalah 3,89, ini adalah angka yang cukup tinggi yang menunjukan bahwa karyawan setuju dengan pernyataan diatas. Digital Marketing tentu memudahkan karyawan berkomunikasi dengan stakeholder, yaitu melalui e-mail, jejaring sosial, maupun akun komunikasi personal seperti WhatsApp, Line, maupun Facebook Messenger.
Tabel 8. Analisa Deksriptif Dimensi Features

\begin{tabular}{|c|c|c|c|c|c|c|c|}
\hline \multirow{2}{*}{ Indikator } & \multicolumn{5}{|c|}{ Jawaban } & \multirow{2}{*}{ Mean } & $\begin{array}{c}\text { Std. } \\
\text { Dev. }\end{array}$ \\
\cline { 2 - 7 } & STS & TS & N & S & SS & & \\
\hline $\begin{array}{l}\text { Digital Marketing memiliki } \\
\text { teknologi up to date (Y2.1) }\end{array}$ & 0 & 3 & 29 & 66 & 22 & 3,89 & 0,856 \\
\hline $\begin{array}{l}\text { Digital Marketing memiliki } \\
\text { database pelanggan (Y2.2) }\end{array}$ & 0 & 5 & 31 & 69 & 15 & 3,78 & 0,845 \\
\hline
\end{tabular}

Features adalah fitur-fitur yang dimiliki oleh Perceived Quality, pada indikator Y2.1 dapat dilihat memiliki nilai Mean 3,89, yang artinya para karyawan setuju dengan adanya Digital Marketing yang memiliki teknologi up to date yang akan menunjang persepsi pelanggan yang dapat berdampak langsung terhadap kinerja karyawan, yaitu mempermudah karyawan dengan cara mengedukasi dan menarik minat pelanggan.

Indikator Y2.2 memiliki Mean yang cukup tinggi yaitu 3,78, dimana Digital Marketing akan meningkatkan kepemilikan jumlah database pelanggan dari perusahaan. Dengan menggunakan Digital Marketing, para pelanggan harus mendaftar dan mengisi database yang nantinya akan menjadi aset perusahaan. Ini akan meningkatkan nilai-nilai yang dimiliki perusahaan secara otomatis, data-data ini pun dapat dijual nantinya dan akan masuk sebagai BigData.

Tabel 9. Analisa Deksriptif Dimensi Reliability

\begin{tabular}{|c|c|c|c|c|c|c|c|}
\hline \multirow{2}{*}{ Indikator } & \multicolumn{5}{|c|}{ Jawaban } & \multirow{2}{*}{ Mean } & \multirow{2}{*}{$\begin{array}{l}\text { Std. } \\
\text { Dev. }\end{array}$} \\
\hline & STS & TS & $\mathbf{N}$ & $\mathbf{S}$ & SS & & \\
\hline $\begin{array}{l}\text { Digital Marketing mampu } \\
\text { membantu karyawan } \\
\text { memberikan informasi }(Y 2.3)\end{array}$ & 0 & 5 & 31 & 66 & 18 & 3,81 & 0,697 \\
\hline $\begin{array}{lr}\text { Digital } & \text { Marketing } \\
\text { memudahkan } & \text { karyawan } \\
\text { berkomunikasi } & \text { dengan } \\
\text { pelanggan (Y2.4) } & \\
\end{array}$ & 0 & 5 & 41 & 49 & 25 & 3,78 & 0,709 \\
\hline
\end{tabular}

Reliability adalah Digital Marketing yang dapat diandalkan, dapat kita lihat pada indikator Y2.3 yaitu Digital Marketing mampu membantu karyawan dalam memberikan informasi maupun menyampaikannya. Dengan nilai Mean 3.81 dapat disimpulkan bahwa para karyawan setuju dengan pernyataan tersebut, karena Digital Marketing dapat secara langsung memberikan informasi tanpa perlu kita jelaskan. Pelanggan dapat secara langsung melihat informasi yang terdapat di website maupun akun sosial perusahaan.

Indikator Y2.4 dengan nilai Mean 3,78 mendukung indikator Y2.3, yaitu Digital Marketing memudahkan karyawan berkomunikasi dengan pelanggan, dengan adanya akun komunikasi personal, hal ini dapat memudahkan karyawan untuk berkomunikasi secara langsung dan cepat. Komunikasi yang terjadi adalah 2 arah dan tidak ada halangan maupun 
hambatan yang terjadi, komunikasi tersebut terjadi secara real-time dan tidak ada tunggu menunggu untuk menyampaikan pesan sehingga informasi yang diberikan akan secara langsung tersampaikan kepada pelanggan.

Tabel 10. Analisa Deksriptif Dimensi Conformance

\begin{tabular}{|l|c|c|c|c|c|c|c|}
\hline \multirow{2}{*}{ Indikator } & \multicolumn{5}{|c|}{ Jawaban } & \multirow{2}{*}{ Mean } & $\begin{array}{c}\text { Std. } \\
\text { Dev. }\end{array}$ \\
\cline { 2 - 7 } & STS & TS & N & S & SS & & \\
\hline $\begin{array}{l}\text { Digital Marketing mampu } \\
\text { memberikan keamanan bagi } \\
\text { pelanggan (Y2.5) }\end{array}$ & 0 & 7 & 32 & 65 & 18 & 3,80 & 0,734 \\
\hline $\begin{array}{l}\text { Digital Marketing membantu } \\
\text { karyawan dalam meyakinkan } \\
\text { pelanggan (Y2.6) }\end{array}$ & 0 & 3 & 31 & 73 & 13 & 3,80 & 0,818 \\
\hline
\end{tabular}

Conformance adalah kesesuaian yang terjadi antara karyawan dan pelanggan, baik dalam hal kemanan maupun kepercayaan. Dalam indikator Y2.5 dapat kita lihat bahwa nilai Mean adalah 3,80 nilai yang cukup tinggi ini membuktikan bahwa Digital Marketing mampu memberikan keamanan bagi pelanggan, yaitu dengan cara merahasiakan data-data pribadi pelanggan yang sudah mereka isi pada saat pendaftaran pertama.

Diikuti dengan Indikator Y2.6 yang juga memiliki nilai Mean 3,80 Digital Marketing dapat membantu karyawan dalam meyakinkan pelanggan, dengan web design yang menarik dan situs yang berisi informasi yang berbobot, tentu pelanggan akan semakin tertarik melihat dan mencari tau tentang perusahaan maupun produk yang kita sedang pasarkan.

Dapat dikatakan bahwa kedua indikator ini sama pentingnya karena memiliki nilai Mean yang sama persis yaitu 3,80. Hal ini disebabkan karena adanya hubungan dengan keamanan dan kepercayaan yang kita dapatkan dari para pelanggan. Apabila kita sudah memberikan garansi keamanan yang memuaskan, tentu pelanggan tanpa segan akan memberikan kepercayaan yang tinggi terhadap perusahaan.

Tabel 11. Analisa Deksriptif Dimensi Durability

\begin{tabular}{|c|c|c|c|c|c|c|c|}
\hline \multirow{2}{*}{ Indikator } & \multicolumn{5}{|c|}{ Jawaban } & \multirow{2}{*}{ Mean } & $\begin{array}{c}\text { Std. } \\
\text { Dev. }\end{array}$ \\
\cline { 2 - 8 } & STS & TS & N & S & SS & & \\
\hline $\begin{array}{l}\text { Digital Marketing aman dari } \\
\text { hacker (Y2.7) }\end{array}$ & 0 & 2 & 28 & 71 & 19 & 3,89 & 0,737 \\
\hline $\begin{array}{l}\text { Digital Marketing memiliki } \\
\text { konsistensi yang baik (Y2.8) }\end{array}$ & 0 & 4 & 29 & 70 & 17 & 3,83 & 0,653 \\
\hline
\end{tabular}

Durability adalah ketahanan dari Digital Marketing itu sendiri, apakah Digital Marketing tersebut aman dari gangguan hacker yang ada, dalam hal ini, dengan nilai Mean 3,89 para karyawan setuju dengan adanya programmer yang handal akan membuat website, akun media sosial, maupun akun chatting peronal akan aman dari hacker dan tidak akan bocor identitas maupun password. Indikator Y2.7 ini menunjukan bahwa Digital Marketing yang digunakan sudah aman dari gangguan hacker maupun gangguan lainnya.

Indikator Y2.8 ini mengindikasikan bahwa karyawan setuju dengan Digital Marketing yang mereka miliki, bahwa Digital Marketing yang mereka miliki memiliki konsistensi yang baik, yang dimaksud konsistensi yang baik adalah situs yang tidak mudah down, akun jejaring sosial yang aktif, maupun akun chatting resmi perusahaan/customer service online via WhatsApp yang selalu aktif dalam memberikan solusi-solusi maupun menerima kritik dan saran dari para pelanggan yang mempunyai opini tersendiri.

Indikator Y2.7 dan Y2.8 memiliki hubungan yang cukup erat, karena apabila akun tersebut sudah terkena hack, maka kepercayaan yang sudah dibangun tersebut akan hilang dan reputasi perusahaan pun akan menurun karena ketidakpercayaan para pelangan terhadap perusahaan.

Tabel 12. Analisa Deksriptif Dimensi Serviceability

\begin{tabular}{|c|c|c|c|c|c|c|c|}
\hline \multirow{2}{*}{ Indikator } & \multicolumn{5}{|c|}{ Jawaban } & \multirow{2}{*}{ Mean } & \multirow{2}{*}{$\begin{array}{c}\text { Std. } \\
\text { Dev. }\end{array}$} \\
\hline & STS & TS & $\mathbf{N}$ & $\mathbf{S}$ & SS & & \\
\hline $\begin{array}{l}\text { Digital Marketing mampu } \\
\text { memberikan pelayanan } \\
\text { terbaik (Y2.9) }\end{array}$ & 0 & 6 & 26 & 63 & 25 & 3,89 & 0,668 \\
\hline $\begin{array}{l}\text { Digital Marketing mampu } \\
\text { menanggapi komplain } \\
\text { pelanggan }(Y 2.10)\end{array}$ & 0 & 4 & 23 & 76 & 17 & 3,88 & 0,699 \\
\hline
\end{tabular}

Serviceability adalah kemudahan servis maupun perbaikan ketika sedang dibutuhkan oleh pelanggan. Hal ini tentu saja harus diperhatikan apabila Digital Marketing yang sedang kita gunakan terkena serangan hack maupun down (rusak).

Pada indikator Y2.9 Digital Marketing mampu memberikan pelayanan terbaik, bantuan Digital Marketing yaitu situs perusahaan sudah mampu memberikan layanan yang terbaik, dengan arti pelanggan bisa mendapatkan informasi dengan mudah, tidak rumit dalam pencarian info maupun tidak menyulitkan pelanggan dalam menggunakan internet. Karyawan setuju bahwa Digital Marketing yang mereka gunakan mampu memberikan pelayanan terbaik, sebab dengan hal itu, pelanggan dapat dengan mudah mencari info tanpa karyawan harus memberikan penjelasan-penjelasan umum. Dalam hal ini karyawan sangat terbantu dengan Digital Marketing. Nilai Mean 3,89 menjadi acuan bahwa karyawan merasa terbantu dengan adanya Digital Marketing.

Digital Marketing mampu menanggapi komplain pelanggan, dalam situs yang dibuat perusahaan, tentu akan ada kolom komentar,kritik, dan saran, hal ini sudah dirasakan karyawan dan hal tersebut 
membuat mereka mengerti tentang apa saja yang perlu diperhatikan secara ekstra. Indikator Y2.10 ini memiliki nilai Mean 3,88, nilai yang cukup tinggi dan dapat dikatakan bahwa para karyawan yang mengisi kuisioner ini setuju dengan pernyataan bahwa Digital Marketing yang merka gunakan mampu mengatasai komplain dari para pelanggan.

Tabel 13. Analisa Deksriptif Dimensi Aesthetic

\begin{tabular}{|c|c|c|c|c|c|c|c|}
\hline \multirow{2}{*}{ Indikator } & \multicolumn{5}{|c|}{ Jawaban } & \multirow{2}{*}{ Mean } & $\begin{array}{c}\text { Std. } \\
\text { Dev. }\end{array}$ \\
\cline { 2 - 8 } & STS & TS & N & S & SS & & 0,783 \\
\hline $\begin{array}{l}\text { Digital Marketing memiliki } \\
\text { tampilan yang menarik (Y2.11) }\end{array}$ & 0 & 6 & 32 & 61 & 21 & 3,81 & 0,673 \\
\hline $\begin{array}{l}\text { Digital Marketing memiliki } \\
\text { tampilan yang modem (Y2.12) }\end{array}$ & 0 & 3 & 31 & 70 & 16 & 3,83 & 0,673 \\
\hline
\end{tabular}

Aesthetic merupakan estetika dari sebuah situs, yaitu keindahan, komposisi, konstruksi dan penataan daripada situs itu sendiri. Indikator Y2.11 memiliki nilai Mean 3,81. Nilai ini menandakan bahwa karyawan setuju dengan pernyataan bahwa Digital Marketing yang mereka buat memiliki tampilan yang menarik, hal ini sangat berpengaruh dan berdampak kepada pelanggan. Tampilan dan desain yang menarik akan membuat pelanggan betah berlama-lama di situs anda. Oleh sebab itu desain dan tampilan yang menarik seringkali diunggulkan dalam sebuah situs.

Indikator Y2.12 juga disetujui oleh sebagian besar karyawan. Dengan nilai Mean 3,83 dapat disimpulkan bahwa karyawan juga memiliki Digital Marketing dengan tampilan yang modern, hal ini juga mempengaruhi keinginan pelanggan untuk berlamalama disitus anda, selai konten dan isi yang menarik, desain yang futuristik akan menarik perhatian para peanggan dan membuat mereka untuk ingin mengeksplor lagi website yang sudah anda buat dan beri tema yang modern.

Estetika merupakan hal penting yang wajib diperhatikan dalam sebuah situs maupun Digital Marketing lainnya. Tanpa estetika tentu desain dan tampilan situs tersebut menjadi berhamburan dan tanpa adanya tujuan. Tampilan desain yang menarik dan modern tentu meningkatan hasrat para pelanggan untuk menggali informasi lebih dalam tentang situs tersebut.

Tabel 14. Analisa Deksriptif Dimensi Role Set

\begin{tabular}{|l|c|c|c|c|c|c|c|}
\hline \multirow{2}{|c|}{ Indikator } & \multicolumn{5}{|c|}{ Jawaban } & \multirow{2}{*}{ Mean } & $\begin{array}{c}\text { Std. } \\
\text { Dev. }\end{array}$ \\
\cline { 2 - 6 } & STS & TS & N & S & SS & & \\
\hline $\begin{array}{l}\text { Digital Marketing membantu } \\
\text { membangun hubungan kerjasama } \\
\text { team (Z1.1) }\end{array}$ & 0 & 3 & 25 & 73 & 19 & 3,90 & 0,778 \\
\hline $\begin{array}{l}\text { Digital Marketing memudahkan } \\
\text { karyawan dalam melayani } \\
\text { konsumen (Z1.2) }\end{array}$ & 0 & 6 & 30 & 69 & 15 & 3,78 & 0,679 \\
\hline
\end{tabular}

Digital Marketing membantu hubungan kerjasama team, dikarenakan komunikasi yang mudah, intens, dan berisi. Akun jejaring sosial, website, dan messenger sangat membantu dalam hal ini, karyawan dapat mengirimkan pesan dan dibaca pada saat itu juga, sehingga pertukaran informasi yang terjadi otomatis meningkat dalam segi kecepatan, efisiensi akan tercipta dan kerjasama team yang bagus akan terjadi seiring dengan pertukaran informasi yang cepat. Dapat kita lihat Indikator Z1.1 dengan nilai Mean 3,90 bahwa karyawan setuju dengan hal tersebut.

Indikator Z1.2 memiliki nilai Mean 3,78, dalam hal ini dapat dikatakan bahwa Digital Marketing memudahkan karyawan dalam melayani konsumen, dengan adanya Digital Marketing, karyawan dapat menanggapi konsumen secara cepat dan tepat. Dengan bantuan Akun jejaring sosial, frekuensi karyawan untuk berbicara dengan pelanggan akan berkurang, hal ini dikarenakan dalam jejaring sosial, karyawan dapat membalas komentar dan meningkatkan efisiensi pekerjaan.

Tabel 15. Analisa Deksriptif Dimensi Role Script

\begin{tabular}{|l|c|c|c|c|c|c|c|}
\hline \multirow{2}{*}{ Indikator } & \multicolumn{5}{|c|}{ Jawaban } & \multirow{2}{*}{ Mean } & $\begin{array}{c}\text { Std. } \\
\text { Dev. }\end{array}$ \\
\cline { 2 - 8 } & STS & TS & N & S & SS & & \\
\hline $\begin{array}{l}\text { Digital Marketing meningkatkan } \\
\text { kualitas layanan hotel (Z1.3) }\end{array}$ & 0 & 4 & 27 & 69 & 20 & 3,88 & 0,676 \\
\hline $\begin{array}{l}\text { Digital Marketing memudahkan } \\
\text { hotel memberikan layanan yang } \\
\text { berkesinambungan (Z1.4) }\end{array}$ & 0 & 7 & 26 & 76 & 11 & 3,76 & 0,724 \\
\hline
\end{tabular}

Indikator Z1.3 memiliki nilai Mean yang cukup tinggi, yaitu 3,88, dalam hal ini dapat diindikasikan bahwa karyawan setuju dengan pernyataan tersebut, yaitu Digital Marketing meningkatkan kualitas layanan hotel. Dengan adanya Digital Marketing karyawan merasa terbantu dalam meningktkan kualitas layanan hotel, karena dalam website maupu situs yang dimiliki oleh perusahaan, pelanggan dapat secara langsung melihat, memesan, maupun membayar layanan yang mereka inginkan.

Digital Marketing memudahkan hotel emberikan layanan yang berkesinambungan, Indikator Z1.4 ini memiliki nilai Mean yaitu 3,76 yang berarti benar adanya bahwa karyawan merasa bahwa Digital Marketing membantu mereka dan memudahkan hotel memberikan layanan. Hal ini disebabkan karena pelanggan dapat secara langsung memesan semua yang layanan yang ada.

Tabel 16. Analisa Deksriptif Dimensi Role Congruence

\begin{tabular}{|c|c|c|c|c|c|c|c|}
\hline \multirow{2}{*}{ Indikator } & \multicolumn{5}{|c|}{ Jawaban } & \multirow{2}{*}{ Mean } & \multirow{2}{*}{$\begin{array}{l}\text { Std. } \\
\text { Dev. }\end{array}$} \\
\hline & STS & TS & $\mathrm{N}$ & $\mathrm{S}$ & SS & & \\
\hline $\begin{array}{lrr}\text { Digital } & \text { Marketing } & \text { membantu } \\
\text { hotel dalam } & \text { menarik } \\
\text { pelanggan }(\mathrm{Z} 1.5) & \end{array}$ & 0 & 2 & 24 & 80 & 14 & 3,88 & 0,714 \\
\hline $\begin{array}{l}\text { Digital Marketing membantu } \\
\text { hotel dalam memberikan } \\
\text { informasi (Z1.6) }\end{array}$ & 0 & 4 & 26 & 69 & 21 & 3,89 & 0,695 \\
\hline
\end{tabular}

Indikator Z1.5 memiliki nilai mean 3,88, yaitu Digital Marketing membantu hotel dalam menarik pelanggan, hal ini disebabkan karena Digital 
Marketing meningkatkan keinginan pelanggan dengan desain situs yang menarik, hal ini juga dapat didukung dengan situs yang tidak rumit serta mudah untuk diakses. Apabila situs dan website yang dituju sulit untuk diakses, kecenderungan pelanggan akan berganti dan akan berpindah ke website atau situs yang lain. Dalam hal ini 66\% karyawan setuju dengan pernyataan diatas.

Pernyataan diatas dapat kita artikan bahwa Digital Marketing mampu membantu karyawan dalam memberikan informasi maupun menyampaikannya. Dengan nilai Mean 3.89 dapat disimpulkan bahwa para karyawan setuju dengan pernyataan tersebut, karena Digital Marketing dapat secara langsung memberikan informasi tanpa perlu kita jelaskan. Pelanggan dapat secara langsung melihat informasi yang terdapat di website maupun akun sosial perusahaan.

Tabel 17. Analisa Deksriptif Dimensi Role Expansion

\begin{tabular}{|l|c|c|c|c|c|c|c|}
\hline \multirow{2}{*}{ Indikator } & \multicolumn{5}{|c|}{ Jawaban } & \multirow{2}{*}{ Mean } & $\begin{array}{c}\text { Std. } \\
\text { Dev. }\end{array}$ \\
\cline { 2 - 7 } & STS & TS & N & S & SS & & \\
\hline $\begin{array}{l}\text { Digital Marketing membantu } \\
\text { hotel dalam memperoleh } \\
\text { pelanggan baru (Z1.7) }\end{array}$ & 0 & 4 & 22 & 79 & 15 & 3,88 & 0,608 \\
\hline $\begin{array}{l}\text { Digital Marketing membantu } \\
\text { karyawan dalam banyak tugas } \\
\text { (multi task) (Z1.8) }\end{array}$ & 0 & 6 & 20 & 79 & 15 & 3,86 & 0,716 \\
\hline
\end{tabular}

Digital Marketing membantu hotel dalam memperoleh pelanggan baru, dengan nilai Mean 3,88, dapat kita artikan bahwa karyawan setuju dengan Digital Marketing yang membantu memperoleh pelanggan baru, hal ini bisa dijelaskan dalam pembuatan website yang menarik dan modern akan menarik perhatian pelanggan dan meningkatkan keinginan pelanggan untuk mengetahui lebih dalam mengenai website ataupun situs perusahaan tersebut. Dari hal tersebut dapat diartikan bahwa dengan memberikan Digital Marketing dapat membantu karyawan dalam memperoleh pelanggan.

Indikator Z1.8 memiliki nilai Mean 3,86, karyawan tentu setuju dengan pernyataan tersebut, Digital Marketing sangat membantu, aplikasi-aplikasi yang ada di handphone maupun internet dapat membantu karyawan dalam mengerjakan banyak tugas sekaligus, baik trik-trik kecil maupun cara-cara yang sudah tersedia untuk mempersingkat waktu kerja dapat kita lakukan dengan cara mengikuti petunjuk-petunjuk yang ada di internet.

Discrepancy merupakan kesenjanganyang terjadi di bawah pemenuhan antara aktual dan aspek direncanakan. Pada dimensi ini dapat kita lihat indikator Z1.10 memiliki mean sebesar 3,88 yang berarti para karyawan setuju bahwa Digital Marketing meningkatkan kreativitas karyawan. Dengan adanya media berupa Digital Marketing ini, mau tidak mau karyawan harus mampu berpikir secara kreatif dan inovatif supaya unggul dari pesaing dan para konsumen semakin tertarik dengan keberadaan dan kemampuan perusahaan.

Tabel 18. Analisa Deksriptif Dimensi Role Discrepancy

\begin{tabular}{|l|c|c|c|c|c|c|c|}
\hline \multirow{2}{*}{ Indikator } & \multicolumn{5}{|c|}{ Jawaban } & \multirow{2}{*}{ Mean } & $\begin{array}{c}\text { Std. } \\
\text { Dev. }\end{array}$ \\
\cline { 2 - 7 } & STS & TS & N & S & SS & & \\
\hline $\begin{array}{l}\text { Digital Marketing membantu } \\
\text { karyawan dalam } \\
\text { berimprovisasi (Z1.9) }\end{array}$ & 0 & 5 & 28 & 69 & 18 & 3,83 & 0,653 \\
\hline $\begin{array}{l}\text { Digital Marketing } \\
\text { meningkatkan kreativitas } \\
\text { karyawan (Z1.10) }\end{array}$ & 0 & 5 & 20 & 79 & 16 & 3,88 & 0,687 \\
\hline
\end{tabular}

Sedangkan pada indikator Z1.9 jugamemiliki mean yang cukup tinggi sebesar 3,83. Z1.9. Digital Marketing digunakan para karyawan dalam berimprovisasi dalam rangka supaya menjadi pembeda diantara yang lainnya dan nantinya akan meningkatkan performa perusahaan.

\section{Evaluasi Patch Coefficient dan Coefficient of Determination}

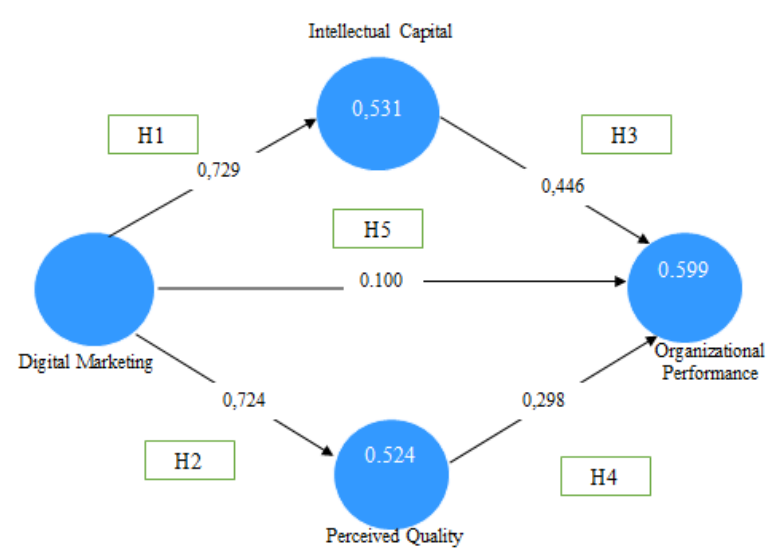

Gambar 2. Path Coefficient dan Coefficient of Determination

Pada analisa path coefficient ini telah dibuktikan bahwa Intellectual Capital dan Perceived Quality memperkuat hubungan antara Digital Marketing dan Organizational Performance. Dari gambar diatas dapat dijelaskan bahwa nilai path coefficientterbesar ditunjukkan dari pengaruh Digital Marketing terhadap Perceived Qualitysebesar 0,724. Sedangkan kontribusi nilai Digital Marketing terhadap Intellectual Capital tidak berbeda jauh, sebesar 0,729. Hubungan menuju Organizational Performance terkuat juga didapat ketika Digital Marketing melewati Intellectual Capital dan Perceived Quality menuju Organizational Performance. Pada hubungan Digital Marketing terhadap Organizational Perfor- 
mancesecara langsung memiliki path coefficient senilai 0,100. Lalu ketika hubungantersebut melalui variabel Intellectual Capital terlebih dahulu, maka nilai dari pathcoefficient meningkat menjadi 0,325 $(=0,729 \times 0,446)$. Sehingga hal inimerupakan bukti bahwa Intellectual Capital merupakan variabel intervening yangmemperkuat hubungan antara Digital Marketing dengan Organizational Performance.

\section{T-Statistic}

Tabel 19. T-Statistic

\begin{tabular}{|c|r|r|r|r|}
\hline & $\begin{array}{c}\text { Original } \\
\text { Sample (0) }\end{array}$ & $\begin{array}{c}\text { SampleMean } \\
\text { (M) }\end{array}$ & $\begin{array}{c}\text { Standard } \\
\text { Error } \\
\text { (STERR) }\end{array}$ & $\begin{array}{c}\text { T Statistics } \\
(\text { (|O/STERR) }\end{array}$ \\
\hline $\begin{array}{c}\text { Digital Marketing - } \\
\text { >Intellectual Capital }\end{array}$ & 0,729 & 0,731 & 0,046 & 15,814 \\
\hline $\begin{array}{c}\text { Digital Marketing - } \\
\text { >Perceived Quality }\end{array}$ & 0,724 & 0,727 & 0,049 & 14,812 \\
\hline $\begin{array}{c}\text { Digital Marketing - } \\
\text { >Organizational } \\
\text { Performance }\end{array}$ & 0,100 & 0,087 & 0,106 & 0,944 \\
\hline $\begin{array}{c}\text { Intellectual Capital - } \\
\text { >Organizational } \\
\text { Performance }\end{array}$ & 0,446 & 0,450 & 0,096 & 4,645 \\
\hline $\begin{array}{c}\text { Perceived Quality -> } \\
\text { Organizational } \\
\text { Performance }\end{array}$ & 0,298 & 0,303 & 0,126 & 2,357 \\
\hline
\end{tabular}

Dengan melihat Tabel 19, dapat diartikan bahwa nilai original sample $(\mathrm{O})$ adalah nilai path coefficient yang menunjukkan kekuatan pengaruh dari satu latent variable ke satu latent variable lainnya. Sedangkan nilai pada kolom sample mean (M) menunjukkan nilai tengah dari path coefficient. Sedangkan standard error (STDERR), menunjukkan nilai error pada sampel mean. Nilai $T$ statistics untuk melihat nilai $T$ hitung yang akan digunakan untuk pengujian hipotesis, dimana $T$ statistics yang memiliki nilai di atas 1,96 memiliki pengaruh.

\section{PEMBAHASAN}

\section{Digital MarketingtoIntellectual Capital}

Hasil penelitian ini menunjukkan bahwa variabel Digital Marketing dari Industri Perhotelan Bintang 3 memiliki pengaruh yang positif terhadap Intellectual Capitaldengan hasil nilai uji T-statistics> 1,96 yaitu sebesar 15,814 .

Dalam menghadapi persaingan saat ini dan keadaan ekonomi yang melambat yang berakibat pada menurunnya pertumbuhan industri hotel, kemampuan perusahaan untuk mengimplementasikan strategi pemasaran penting untuk diperhatikan. Pemasaran Digital yang dimiliki oleh perusahaan harus terus diperhatikan dan dikembangkan mengikuti perkembangan yang ada. Hal ini diharapkanmampu membuat perusahaan bertahan dari fluktuasi ekonomi yang ada demi keberlangsungan perusahaan di masa mendatang.

Namun dalam mempertahankan perusahaan agar tetap bertumbuh tidak bisa hanya bergantung pada Pemasaran Digital yang dimiliki perusahaan. Untuk mempertahankan Pemasaran Digital yang baik diperlukan Intellectual Capital yang mendukung jalannya pemasaran itu sendiri.

Digital Marketing sendiri memiliki nilai path positif terhadap Intellectual Capitalsebesar 0,729. Hal ini menunjukkan bahwa Digital Marketing memiliki pengaruh yang kuat dalam membentuk Intellectual Capitaldari karyawanIndustri Hotel Bintang Tiga.

\section{Digital Marketing to Perceived Quality}

Pada hasil penelitian ini dapat dilihat bahwa Digital Marketing tidak hanya memiliki pengaruh pada Intellectual Capital, namun berpengaruh pula pada Perceived Quality dengan nilai uji T-statistics $>1,96$ yaitu 14,812. Hasil tersebut membuktikan bahwa Digital Marketing memiliki dampak signifikan bagi kemampuan Perusahaan untuk terus belajardan berkembang.

Digital Marketing merupakan salah satu teknik promosi yang baik dan efisien, hal ini dapat berdampak langsung pada perusahaan dengan cara memberikan pelayanan yang baik dan membuat persepsi di masyarakat. Dapat dikatakan bahwa dalam pengaplikasian Digital Marketing memiliki dampak positif dan berhubungan dengan persepsi yang diciptakan kepada para konsumen.

Persepsi yang dibuat oleh Digital Marketing dapat memberikan nilai yang sebelumnya tidak dimiliki oleh perusahaan dengan mencari pasar yang lebih luas, persepsi bahwaperusahaan yang kita miliki adalah perusahaan yang dapat diandalkan. Persepsi yang tercipta ini dapat menjadi sebuah keuntungan perusahaan dalam jangka waktu yang tidak sedikit. Tentunya hal ini menjadi nilai positif yang sangat diinginkan perusahaan dalam menghadapi persaingan yang ada. Di era ini pula, didominasi oleh generasi yang mengandalkan teknologi dan suka semua yang serba cepat dan instan. Persepsi yang tecipta pada karyawan ini akan membantu kinerja dan meningkatkan efisiensi dalam penjelasan informasi .

Apabila melihat pada nilai path coefficient, hubungan dari Digital Marketing menuju Perceived Qualitymemiliki nilai sebesar 0,724 yang merupakan hubungan positif. Hal ini berarti keberadaan Digital Marketing mampu berperan dalam mendorong organisasi untuk terus belajar supaya mampu menjadi perusahaan yang unggul di perindustrian asuransi.

\section{Intellectual CapitaltoOrganizational Performance}

Dalam penelitian ini dibuktikan bahwa Intellectual Capitalyang dimiliki oleh Industri Perhotelan bintang tiga akan menciptakan Organizational Per- 
formance bagi perusahaan dengan nilai uji $T$-statistics $>1,96$ yaitu senilai 4,645 sehingga disimpulkan bahwa Intellectual Capitalberpengaruh pada peningkatanOrganizational Performance perusahaan.

Intellectual Capital yang dimiliki oleh perusahaan akan meningkatkan hasil yang dapat dicapai oleh sebuah perusahaan. Intellectual Capital dapat mengembangkan aset-aset yang dimiliki perusahaan untuk meningkatkan value aset itu sendiri melebihi value yang seharusnya. Agar dapat meningkatkan hasil dan target dari sebuah perusahaan, dibutuhkan adanya kinerja efektif dan pengaturan asset yang efisien. Hal ini diharapkan membawa pengaruh positif dalam meningkatnya kinerja organisasi.

Selain itu apabila dilihat dari nilai path coefficient, hubungan dari Intellectual Capital menuju Organizational Performance sebesar 0,446, dimana merupakan hubungan yang baik. Nilai ini juga lebih besar jika dibandingkan dengan hubungan langsung antara Digital Marketing dengan Organizational Performance sehingga Intellectual Capital terbukti berperan sebagai variabel intervening. Hal ini mengkonfirmasi bahwa kemampuan memasarkan produk berperan penting dalam meningkatkan kinerja perusahaan.

\section{Perceived Quality toOrganizational Performance}

Nilai Perceived Quality terhadap Organizational Performance pada Industri Perhotelan Bintang Tiga memiliki nilai $t$-Statistic di atas 1,96 , yaitu 2,357 . Nilai ini menunjukkan bahwa hubungan antara Perceived Qualitydan Organizational Performance memiliki nilai yang signifikan.

Seiring berkembangnya zaman, akan diikuti dengan semakin berkembangnya dan semakin kompleksnya persepsi masyarakat, serta diikuti dengan keadaan ekonomi yang semakin berat dan semakin sengitnya persaingan menjadi ancaman bagi perusahaan. Perusahaan harus mampu menghadapi ancaman-ancaman terebut dan tetap bertahan bahkan semakin tumbuh berkembang.

Persepsi masyarakat yang bagus tentang perusahaan tentu menjadi keunggulan tersediri, hal ini dapat merubah pola pikir masyarakat pada umumnya tentang perusahaan. Maka dari itu Perceived Quality membuat persepsi terhadap konsumen agar perusahan memiliki image yang bagus. Keberadaan Perceived Quality ini mendukung pertumbuhan Organizational Performance karena perusahaan yang memiliki persepsi tinggi tentu akan terus maju dan berkembang. Organizational Perormance seringkali diukur melalui profitability, maka dari itu strategi pemasaran yang baik harus diaplikasikan dengan bantuan-bantuan yang ada
Nilai path coefficient dari Perceived Quality terhadap Organizational Performance adalah 0,298. Nilai ini menunjukkan adanya pengaruh yang cukup kuat dari Perceived Quality terhadap Organizational Performance.

\section{KESIMPULAN DAN SARAN}

Dari pembahasan di atas, maka dapat disimpulkan bahwa Digital Marketing merupakan faktor penting yang dibutuhkan Industri Perhotelan Bintang Tiga untuk terus berkembang dan dapat menghadapi persaingan dalam industri perhotelan. Hal ini dibuktikan dalam perhitungan bahwa Digital Marketing memiliki pengaruh terhadap Intellectual Capital dan Perceived Quality yang berperan dalam meningkatkan Organizational Performance.

Industri Perhotelan Bintang Tiga dapat meningkatkan efisiensi dari Digital Marketing. Langkah ini penting bagi perusahaan karena hal ini dapat meningkatkan jumlah pelanggan. Industri Perhotelan Bintang Tiga dapat lebih menspesifikasikan target pelanggan yang mereka inginkan dalam penggunaan Digital Marketing, dalam pengefisiannya, dapat mendapatkan data dari para pengumpul data. Hal itu akan berpengaruh secara signifikan terhadap hasil dari Digital Marketing itu sendiri.

\section{DAFTAR PUSTAKA}

Aaker, D. (2003), "The power of the branded differentiator", Sloan Management Review, Fall, pp. 83-87.

Abdillah, W., \& amp; Hartono, J. (2015). Partial Least Square (PLS) Alternatif Stuctural Equation Modeling (SEM) dalam Penelitian Bisnis (Cetakan 1). Yogyakarta: Penerbit Andy.

Broderick, A. J., \& Broderick, A. J. (2006). Role theory, role management and service performance.

Evaggelia, F. (2015). Intellectual Capital \& Organizational Advantage: an economic approach to its valuation and measurement. International Journal of Information, Business \& Management, 7(1), 36-57.

Garvin, David A. (1984). "What Does 'Product Quality' Really Mean?" MIT Sloan Management Review. 26(1).

Kim, E. Y., \& Kim, Y. (2011). Predicting online purchase intentions for clothing productsnull. European Journal of Marketing, 38(7), 883897. http://doi.org/10.1108/03090560410539302

Malhotra, N. K. (2004). Marketing research: An applied orientation (4th Edition). New Jersey: Upper Saddle River.

Malhotra, N.K. (2007). Marketing Research, an Applied Orientation. New Jersey: Pearson Education. 
Stewart, T. (1997). Intellectual Capital: The New Wealth of Organizations. Nicholas Brealey Publishing, Business Digest, New York.
Sugiyono. (2009). Metode penelitian bisnis: pendekatan kuantitatif, kualitatif, dan $R \& D$ (Cetakan 14). Bandung: Alfabeta. 